\title{
FINALITY OF JUDGMENTS IN CIVIL CASES AND RELATED CONSIDERATIONS: THE EXPERIENCE OF UKRAINE AND LITHUANIA
}

\author{
Kostiantyn Gusarov \\ Doctor of Law, Professor, Head of the Department \\ of Civil Procedure, \\ Yaroslav Mudryi National Law University, Ukraine
}

Viktor Terekhov

PhD in Law, Lecturer of the Private Law Department, Law Faculty, Vilnius University, Lithuania

doi.org/10.33327/AJEE-18-2.4-a000020

\begin{abstract}
Summary: - 1. Introduction. - 2. The Concept of Finality and its Relevance. 3. Considerations Related to Finality. -3.1 . View of the Court. -3.2 . View of the (Post-) Soviet Doctrine. - 3.3. Considerations that Support Finality. - 4. The Experience of Ukraine. - 5. The Experience of Lithuania. - 6. Possible Implications for the Two Nations. - 7. Conclusions.
\end{abstract}

Finality of judgments is a concept that puts an end to the trial, prohibiting subsequent appeals, opening of new proceedings and disputing clearly established facts. Despite being promoted by the Council of Europe and its Court of Human Rights and familiar to most if not all states, its application still encounters misunderstanding in some Eastern European Countries. Deeply rooted ideas of substantive truth and public role of the judiciary, a rather idiosyncratic notion of fair trial and the rule of law all lead to underestimation of the role played by finality in a peaceful life of the society. This article addresses the experience of Ukraine (where a major judicial reform has just taken place) and Lithuania - two postSoviet nations that both, still in their unique way, worked on implementing the principle of finality into their procedural order. The paper also explores an uneasy balance to be found between this notion and other relevant considerations (access to justice, rule of law, judicial economy and some other).

Keywords: finality of judgments, legal effect, res judicata, review of judicial decisions, access to justice, rule of law, correction of errors, judicial economy. 


\section{INTRODUCTION}

As Ukraine approaches deeper integration with the European Union, it faces necessity of modernizing its legislation and harmonizing it with European supranational standards. Of course, membership is not the only reason for change. Ukrainian judicial system used to be biased, partly corrupted, while the procedures for case deliberation - slow and ineffective. ${ }^{1}$ Not only were they behind the standards of the EU, but also contravening the positive obligations under the European Convention on the protection of human rights, which resulted in a number of cases lost before the ECtHR. ${ }^{2}$ With that in mind, a comprehensive reform of judicature and procedural law was envisaged, which resulted in a law of 3 October 2017. ${ }^{3}$ It brought changes to the structure of the Courts and their competence, as well as updated the major procedural Codes. Changes affected the role of the judge, grounds of jurisdiction, simplified proceedings, the use of ICT in civil trials and much more.

This article will, however, focus on that part of the reform which is related to finality of judgments. As is widely known, each dispute shall conclude at some point by providing an unambiguous and mandatory solution. The decision pronounced becomes res judicata and cannot be disputed by the parties or changed by the courts, as well as put into question in some other way. Obvious as they are, such ideas still face misunderstanding in many post-Soviet jurisdictions, including Ukraine. The judiciary here was always characterized by a complex structure, numerous instances, a wide discretion of changing and putting aside decisions of the lower courts, and quite extended powers of public officials. All of these were not the result of malice, but rather existed due to specific understanding of the role of the judiciary, rights and obligations of parties and the essence of rule of law and fair trial. At the same time, participation in the European Convention requires taking into account interpretations given by the ECtHR, which was quite fruitful with respect to finality, res judicata and the principle of legal certainty. ${ }^{4}$

The recent reform, although not obvious from the first sight, attaches great importance to the given question. The aim is not only to formally comply with certain European ideals and values, but to modernize national law in that regard, find an appropriate balance between varying interests and to ensure fair trial and effective administration of justice.

Together with experience of Ukraine, we analyze the experience of Lithuania, another country of the former USSR that succeeded in becoming member of the European Union and to change its procedural rules to encompass ECtHR standards. A major

1 Iryna Izarova, 'Reform of the Civil Process in Ukraine: Novels of Lawsuit' (2017) 8 Law of Ukraine 35; Vladislava Pukhalenko, 'Legal Bases of Cooperation between the European Union and Ukraine in the Field of Civil Justice'(2014) 126 Problems of Legality 216-225.

2 Iryna Bezzub, 'Reform of procedural law in Ukraine: expert assessment' Social Communication Research Center <http://www.nbuviap.gov.ua/index.php?option=com_content\&view=article\&id= 3009:reforma-protsesualnogo-zakonodavstva-v-ukrajini-otsinki-ekspertiv\&catid=8\&Itemid=350> accessed 7 December 2019.

3 The Law of Ukraine N 2147-VIII (3 October 2017) 'On the Amendment of Economic Procedural Code, Civil Procedural Code, Code of Administrative Procedure and Other Legal Acts; <http://search. ligazakon.ua/1_doc2.nsf/link1/T172147.html> accessed 7 December 2019.

4 Dovydas Vytkauskas and Grigoriy Dikov, Protecting the Right to a Fair Trial under the European Convention on Human Rights (Council of Europe 2012). 
reform of Civil Procedural Law took place there back in 2002, and since then it functions in a decent way. Certainly, there are states in Europe and worldwide with (presumably) more developed and structured civil justice systems, the quality of which has been tested throughout decades if not centuries. However, their example cannot be directly transposed to Ukraine, having in mind differences in legal culture, economic development and historical background. At the same time, Lithuania is, most probably, the closest Ukrainian ally in the West: they have always had close political, social and economic ties and for quite long have been part of one nation (1340-1648, 1795-1917, 1940-1991) with the same laws applicable to both. As will be seen later, the notion of finality was always of great importance to the two countries.

The article is structured as follows. Part I discusses the concept of finality and its relevance for both private and public stakeholders. Part II explores related considerations that apply to court procedures and decisions, and that contend, support or even outweigh the need to keep judgments stable and unaltered. The problems faced by the courts in application of these doctrines are also discussed there. In Parts III and IV we show the corresponding experience of Ukraine and Lithuania in bringing their legislation in accordance with the requirements of finality (as it concerns the most problematic spheres - judicial review and reopening of proceedings). Part $\mathrm{V}$ tries to propose solutions that can be adopted by both states in order to further improve their regulation. The paper concludes by giving authors' opinion on keeping a delicate balance between finality and other fundamental considerations.

\section{THE CONCEPT OF FINALITY AND ITS RELEVANCE}

Finality of judgments is a concept (or, a legal principle), according to which the decision taken by the court at some point becomes permanent, immutable, binding and open to enforcement. ${ }^{5}$ It cannot be disputed again, the parties may not lodge similar claims and give another interpretation to the established facts in subsequent proceedings on an interrelated matter.

The reason for such adherence to finality is that justice has been performed: a court established relations between parties, settled their dispute and gave its opinion on their rights and duties. Certainly, one or even both of the parties may be dissatisfied with the result, but allowing them subsequent forum for quarrels and altercation is not the best thing society can do for them. It involves additional time and money, the waste of judicial resources and, presumably, lack of justice for other people seeking relief. ${ }^{6}$ Courts are not one's pocket army: their aim is to resolve conflicts and not to maintain them indefinitely. Moreover, they are part of the judiciary, one of the three powers of a sovereign nation. In that regard, they shall have a high status, as their decisions bring stability and order. If, however, they are not respected and are easily changed or overturned, courts are likely to lose faith and support among people. In other words, their decisions must be

5 Thomas A Engelhard, 'Bringing More Finality to Finality: Conditional Consent Judgments and

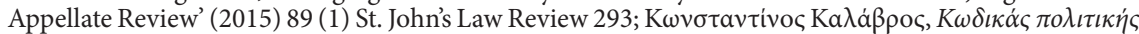

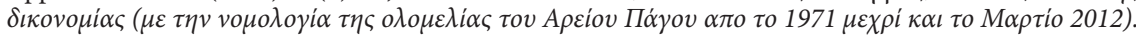

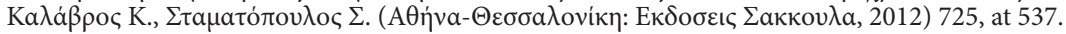

To some degree, duplicate proceedings or persisting appeals may be seen as an abuse of rights. See: Paul M Perell, 'Res judicata and Abuse of Process' (2001) 24 Advocates Quarterly 189. 
worth something, which is not the case where they are easily overwritten by subsequent resolutions. ${ }^{7}$ Thus, it is fair to say that there are both public and private considerations for the application of finality doctrine. ${ }^{8}$

To establish finality of a judgment is also important for other reasons. In this way, a final judgment is a precondition for applying to the European Court of Human Rights and, sometimes, to national institutions of constitutional control. In Ukraine, for instance, the Constitution prescribes since 2016 that a final decision shall also be present for lodging a constitutional complaint, ${ }^{9}$ and since July 2017 the conditions and requirements of finality have been enshrined in the Law on Constitutional Court of Ukraine. ${ }^{10}$

The rules on finality are found in most national legal systems; however their exact contents and scope vary significantly. A great job of harmonizing national laws on the matter was done by the European Court of Human Rights (ECtHR), which is capable of providing binding guidance for the Contracting States to the European Convention. For the Court, finality is a part of the rule of law, a legal principle which is a part of the common heritage of the Contracting States. ${ }^{11}$ From that principle ECtHR derives legal certainty, which requires inter alia respect for res judicata (once again a principle of law). The latter term has for the Court a similar meaning to that of finality:

No party is entitled to seek a review of a final and binding judgment merely for the purpose of obtaining a rehearing and a fresh determination of the case. ${ }^{12}$

In other words: you are precluded as a party from starting litigation anew if matters under consideration have already been resolved. The ECtHR has given almost the same definition to res judicata as originally attached to that doctrine in common law, where it was seen as a matter that has been adjudicated and that bans subsequent litigation on the same matter. ${ }^{13}$

However, differences are also obvious: while res judicata was intended to bar continued litigation of the same case ${ }^{14}$ the Court attached more attention to wrongly initiated

7 See: William E Pomeranz, 'Supervisory Review and the Finality of Judgments under Russian Law' (2009) 34 Review of Central and East European Law 15; Kevin M Clermont, 'Res judicata as Requisite for Justice' (2016) 68 Rutgers University Law Review 1067.

8 The policy choices are usually explained by Latin maxims, such as: interest reipublicae ut sit finis litium ('it is in the interest of the State that there should be an end to litigation'), res judicata pro veritate accipitur ('an adjudged matter is accepted as the truth') and nemo debet bis vexari si constet curiae quod sit pro una et eadem causa ('no one ought to be twice prosecuted where the court establishes that the cause of action is the same').

9 Konstytutsiia Ukraiiny: pryiniata na piatii ses. Verkhovn. Rady Ukraiiny 28.06.1996 (The Constitution of Ukraine: Questions at the fifth session of the Verkhovna Rada of Ukraine) (1996) N 30 Vidomosti Verkhovnoii Rady Ukraiiny141 <http://zakon2.rada.gov.ua/laws/show/254к/96-вp> accessed 7 December 2019.

10 The Law of Ukraine N 35 (13 July 2017) 'On the Constitutional Code of Ukraine' <http://zakon.rada. gov.ua/laws/show/2136-19> accessed 7 December 2019.

11 Brumărescu v Romania, ECtHR Judgment (1999) Application No. 28342/95, 61.

12 Ryabykhv Russia, ECtHR Judgment (2003) Application No 52854/99, 52.

13 Yuval Sinai, 'Reconsidering res judicata: a Comparative Perspective' (2011) 21(2) Duke Journal of Comparative \& International Law 353.

14 Alexander Kornezov, 'Res judicata of National Judgments Incompatible with EU law: Time for a Major Rethink?’ (2014) 51 Common Market Law Review 809. 
appeals and undesirability of changing the decision in higher instances. ${ }^{15}$ Another distinction is that classical res judicata is addressed to the parties (it is they who is barred from starting new litigation and disputing facts in subsequent proceedings; they are also the subjects bound by the court's findings). On the other hand, ECtHR mainly uses this notion in its dialogue with national judiciaries to show them what can and cannot be done to influence the fate of judgment.

It may be said that the Court attaches more relevance to the result rather than the form used. Consequently, it prohibits not only subsequent trials or appeals (and other references to a higher instance), but all other abusive procedural tactics that would lead to the contents of a judgment being modified to the detriment of legal certainty and the right to court (appeals in disguise). ${ }^{16}$

So, does it mean that any reviews are prohibited per se? Not exactly. For some reason national authorities maintain courts of higher instances with review capabilities and allow them to overthrow original decisions. The ECtHR is not against review procedures as such, but rather believes they need to be used in a wise way and be intended to protect some other relevant interest.

\section{CONSIDERATIONS RELATED TO FINALITY}

Like many other concepts enshrined in the Convention (or derived therefrom by the Court) finality - or rather, res judicata, is not absolute. There are other considerations of equal or even prevailing force influencing the status of judgment. We are not speaking here of objective, subjective, temporal and territorial limits to res judicata. These questions are covered in detail elsewhere, ${ }^{17}$ moreover, they are rather specific for each national jurisdiction.

We are rather referring to specific exceptions to the 'principle of finality', which play their role when it appears it may be neglected in favour of another fundamental social value. Such may be equality before law, access to justice (which means that the courts shall be reachable, and the litigants vested with rights to apply as long as they feel it necessary), rule of law (everyone shall have the right to defend even against a judicial institution that may be biased or mistaken in application of law) and other fundamental principles. It is widely believed that finality can never give an absolute immunity against a potential check for common and policy-relevant court errors. ${ }^{18}$

15 See: Brumărescu (n 11); Ryabykh (n 12). However, compare: Esertas v Lithuania, ECtHR Judgment (2012) Application No 50208/06, 31 - the problem was that the courts in the second set of proceedings ignored the previous judicial process (which is contrary to issue preclusion, a part of res judicata doctrine).

16 See: Driza v Albania, ECtHR Judgment (2007) Application No 33771/02, 69-70; Roșca v Moldova, ECtHR Judgment (2005), Application No 6267/02, 26-27.

17 Kornezov, (n 14), 812-813.

18 Serhej Knyazkin, 'Problems of achieving legal certainty at the stage of verification of judicial acts in the civil process' (2017) 6 Bulletin of the Civil Process 60. 


\subsection{View of the Court}

The European Court of Human Rights had recognized the validity of the abovementioned inferences and built up a unique doctrine of permitted reversal of finality. Here are the arguments brought to life by this institution:

1) Priority is always given to stability and immutability of a final decision. Departure from the general rule is only possible when made necessary by circumstances of substantial and compelling character. ${ }^{19}$ Such is the case where some fundamental errors are present and no other remedy is available to address them. ${ }^{20}$ Quite different would be a situation where only some minor, or purely formal questions were brought to justify review. In the latter case, the Court would be most likely to find a violation of legal certainty and res judicata.

2) Judicial reviews are prima facie compatible with the Convention. Since Art. 6 ECHR as such 'does not compel the Contracting States to set up courts of appeal or of cassation,', it is up to the national authorities to determine whether at all and on which conditions review procedures are available. Some of the national jurisdictions indeed see the right to appeal as a necessary remedy. In many legal systems a judgment is not final until the time for its first (and only) appeal lapses. In that sense, the right to appeal is an extension of the right of access to justice, since what you are interested in is not just any judicial institution, but the one which will correctly apply the law and not mess up in the factual base. In case any of this happens, you must be able to further defend your right in the appeal.

There is no problem when a person is entitled to appeal, since the court hearing the case as well as the parties involved in it are not protected from reaching wrong decision (in other words, errare humanum est). ${ }^{22}$ The well-known Recommendation of the Committee of Ministers on the introduction and improvement of the functioning of appeal systems and procedures in civil and commercial cases ${ }^{23}$ also suggests that in principle, it should be possible for any decision of a lower court ('first court') to be subject to the control of a higher court ('second court').

3) Such a control, however, may be effectuated only once (on a particular subject matter). A person may disagree with the original judgment and bring his arguments to a higher instance. To the contrary, repeated setting aside of judgments on the same or similar grounds is incompatible with legal certainty and is not tolerated by the Court. ${ }^{24}$ Enough is enough: courts cannot reasonably hear the same complaints over and over again.

4) Appeal shall be also limited in time. The ECtHR does not provide for specific dates, but notes that a case cannot be open for reconsideration indefinitely. The exact deadlines are

19 Roşca (n 16) 25; Ryabykh (n 12) 51-52.

20 Gudkov v Russia, ECtHR Judgment (2009) Application No 13173/03, 17.

21 See: Delcourt v Belgium, ECtHR Judgment (1970), Application No 2689/65, 25-26; Brualla Gómez de la Torre v Spain, ECtHR Judgment (1997), Applications No 155/1996/774/975, 37.

22 About the court system [of Lithuania] <https://www.apeliacinis.lt/en/court-system/about-the-courtsystem/129> accessed 7 December 2019.

23 Recommendation of the Committee of Ministers on the introduction and improvement of the functioning of appeal systems and procedures in civil and commercial cases No R (95) 5 of 7 February 1995 <https://bit.ly/2KJ9tZt> accessed 7 December 2019.

24 Nikitinv Russia, ECtHR Judgment (2004) Application No 50178/99. 
to be provided in national law, however the Court is free to control their reasonableness and effectiveness (e.g. in relation to reasonable time expectations).

Not only shall the law fix a concrete deadline for review - a limitation needs to be put on the possibility of the court to extend this period or restore missed deadlines. ${ }^{25}$ In this latter case it must be assumed that any potential reason for restoration carries with it the possibility of abuse, since the national judicial authorities may apply them arbitrarily. The possible solution is putting the courts in rigid frameworks that would not allow any broad interpretations.

5) The range of persons to initiate the appeal shall not be broad. These are definitely the parties to the case and other subjects affected by the court's findings, but definitely not some random state officials, such as public prosecutors and court presidents. In certain cases, it is permissible that such subjects launch proceedings for the sake of public policy, yet they have to be limited by other relevant restrictions (e.g. time-limits). In any case, the locus standi of a governmental official before a higher court shall not be better than that of a private party in the original case. ${ }^{26}$

6) Access to higher instances may be (and, reading through the lines, - must be) limited. ${ }^{27}$ Whatever a state calls those instances: appellate, cassation, supervisory - there have to be some filters that would stop unnecessary, unwarranted complaints and open the way only to relevant cases. Normally, a party is given one chance to appeal decision to the court of second instance (see above). However, her attempts to reach further review mechanisms ('third', 'fourth', etc. instance) may be blocked or subject to additional requirements: exhaustion of all previous remedies, presentation of substantial evidence for case reversal, relevance of the case to the precedential practice, necessity to protect some public interest and so on. Besides that, higher courts may establish special panels that would select only significant cases for consideration (all the rest would be simply left behind).

These barriers are not in contradiction with the access to justice, as normally a person is given enough opportunities to defend her private interests before a court, while endless deliberations might indeed constitute an abuse of rights.

7) Closely connected with the previous are the limitations need to be put on the power of higher instances to review the case (and revoke its binding nature). In fact, their powers shall be limited to the correction of judicial errors and miscarriages of justice. ${ }^{28}$ This may be interpreted as meaning that such courts do not normally consider questions of fact, being busy with the problems of proper application of law. Thus, they are not a place for fresh trials, which means that possibilities to raise new claims and bring additional evidence are almost unavailable.

The Court is continuously repeating that 'the mere possibility of two views on the subject

25 See Ponomaryov $v$ Ukraine, ECtHR Judgment (2008) Application No 3236/03, 41.

26 Close to that finding the ECtHR was in Varniene $v$ Lithuania, ECtHR Judgment (2013) Application No 42916/04, 40.

27 Natalia Sukhova, 'Problems of Development of Civil Procedure Law: Trends and Traditions' (2014) 3(40) Herald of Omsk State University. Series 'Law' 154.

Nelyubin v Russia, ECtHR Judgment (2006) Application No 14502/04, 23. 
is not a ground for re-examination. ${ }^{29}$ A party might change her position or decide to add something new. Still, higher instances are not designed for that. The first instance was available and ready to take whatever evidence the person needed for the trial. A fight does not need to continue in subsequent instances, since the task of the court is to settle a conflict (not to keep it open). If all the measures were taken but to no good, the parties shall be stopped from further disputing at least at the price of forcefully imposing some preclusion on them.

It makes sense to place the last judicial instance at the highest judicial organ of the state which knows better the actual problems of the judicial system and is able to eliminate systemic errors made by the courts, and to guarantee uniform application of the law..$^{30}$ This is where its true competence belongs, while the factual grounds of the case are better dealt with by the courts of first instance that are close to population and capable of examining all the relevant matters of the dispute.

From the above we can clearly see that in all cases it is necessary to find a balance between the interests of an individual and the need to ensure effectiveness of the judicial system. The former may want his case reheard time and again, while the state wants to limit attempts to appeal. On the contrary, a person may wish to have his judgment enforced, but it happens that the whole trial was such a manifest challenge to justice and fair trial that in no way it is possible to keep that decision in force. The task of keeping this balance is an uneasy one, luckily some guidelines and failed attempts are provided in the case-law of the ECtHR.

\subsection{View of the (Post-)Soviet Doctrine}

As both Ukraine and Lithuania were part of the vast Soviet empire, the views of the latter on the finality and res judicata still have their relevance and constitute part of the legal heritage. In classic Soviet theory, the doctrine of res judicata was never used. Instead, the concept of the legal effect (of the judgment) was elaborated, which encompassed all the features a judicial act obtained after its entrance into force (binding nature, enforceability, exclusiveness, incontestability and adjudicated nature). Conclusively, it may be said that finality was a consequence of litigation, but never a matter of highest priority. ${ }^{31}$

Firstly, it could be revoked upon intervention of public officials (prosecutors). They had broad authority to question final judgments. Interesting to note that such interventions were done without a request of the parties and sometimes even without them knowing of that fact. The reason was that prosecutors helped the Soviet state to ensure uniform application of law. ${ }^{32}$ Contradictory and erroneous judgments were seen as a clear

$29 \quad$ Nelyubin (n 28) 23 and elsewhere, when the Court faces the re-opening of proceedings for the sole purpose of a rehearing and a fresh determination of the case.

30 Anastacia Rukavishnikova, 'Variability of Understanding the Final Court Judgment in the Decisions of the European Court of Human Rights' (2015) 2(6) Russian Journal of Criminal Law 53-58.

31 Anton Ivanov, 'Principy pravovoj opredelennosti ravnogo pravoprimeneniya' ('Principles of Legal Certainty and Equal Law Enforcement. What is the Role of the Courts?') (2015) 12 Arbitration Practice for Lawyers 98-99.

32 Alexandr F Kleinman, Izbrannye trudy (Selected works), volume 1 (Sovetskaya Kuban 2008) 17. 
violation of zakonnost' (legality) principle which in Soviet legal tradition played the same role as the rule of law.

The fact that private parties did not themselves dispute the decision was of no importance, since, in essence, Soviet Civil Procedure was not an area of 'private litigation' (as opposed to public), as, in the words of Lenin, 'there was nothing private a Soviet State could tolerate in the field of economic activity. ${ }^{33}$ The goals established included the struggle for the strictest compliance with socialist law, strengthening and protection of socialist property, fight against the disrupters of socialist construction and establishing the strictest discipline and self-discipline of the working people. ${ }^{34}$ Protection of private interests was almost lost among these.

Secondly, an important consideration was that of substantive truth. It stands for such a view of the facts of the case that correctly represents objective reality. Courts were intended to seek such truth and did not stop until found it. The fact that judgment was already in force and being implemented was of no hindrance for a review, as the substantive truth was more important. An incorrect judgment did not reflect the objective circumstances of the case and could not be upheld: it had to be declared null and void.

In Soviet states, final decisions could be quashed in a procedure named nadzor (supervision), which gave extensive possibilities to overturn final decisions. Substantive truth was hard to establish, though the broad competence of the judge helped in that regard by obliging parties to bring relevant evidence and to prove certain things. What is also important, the competence of the higher courts was not limited, and they could easily do the same things that are normally possible only in first instance (hear witnesses, examine the written and material evidence, etc.)

It is not that Soviet scholars and practitioners were unaware of the difference between their approach and that of Europe and the US. However, the latter was seen as bourgeois and capitalist, unsuitable and undesirable for socialist society. Soviet law did not tolerate any non-objective truth and any presumption or fiction thereof. In fact, the search for substantive truth was always seen as a great advantage of Soviet civil justice.

The named features (powers of the prosecutor, role of substantive truth and competence of higher instances) are sometimes seen as the most important culturally distinctive features of some post-Soviet procedural systems as well. ${ }^{35}$ Despite there are authors preferring to equate legal effect of judgment with finality and to modernize that concept by bringing it closer to the ideas of res judicata ${ }^{36}$ there are still problems in its understanding in many countries of the former Union. These definitely arise due to reliance on a familiar doctrine and reluctance 'to accept philosophy, according to

33 Vladimir Lenin, Polnoe sobranie sochinenij (Full collection of writings), volume $44<\mathrm{http}: / / \mathrm{uaio}$.ru/vil/ vilall.htm> accessed 8 December 2019.

34 Kleinman (n 32) 25-26.

35 See the study by Dmitrij Maleshin, Grazhdanskaya processual'naya sistema Rossii (Civil Procedural System of Russia) (Statut 2011), where he describes the Russian system of civil procedure (also a postSoviet one) as being 'unique' and 'distinctive', different from both common law and civil law models.

36 Victor Terekhov, Boundaries of the legal force of the court decision: territorial and temporal aspects (author's abstract of dissertation for the degree of candidate of legal sciences) (Yekaterinburg 2014), 14. 
which the idea of judgment's stability as the basis for the final bringing of certainty to the legal relations. ${ }^{37}$

However, it is clear that such beliefs are in contradiction to finality, at least in a way it is interpreted by the ECtHR. Moreover, they are also at variance with the principles of judicial independence, discretionary powers of the parties to the case and even the fundamental idea of the rule of law..$^{38}$ For that reason, the post-Soviet states have nothing better than learn and adapt, sometimes facing strict criticism from the European institutions.

\subsection{Considerations that Support Finality}

Yet some considerations play in favour of finality. Thus, the ideas of 'judicial economy' and procedural concentration also advocate for fewer opportunities to dispute decision, still for a different reason: necessity to preserve public funds and use them wisely. This idea becomes extremely popular in the age of austerity. One dispute of two parties shall be really resolved only once - all further additions, supplements and reconsiderations present an unnecessary burden on judicial system, while the same money may be spent on those really waiting for their disputes to be solved. According to this logic, parties shall be allowed one full-fledged trial (in first instance) and a chance to bring once their clearly defined complaints to a higher instance (appeal). The latter possibility, though, cannot be seen as a 'second round' of the same duel or a revanche for a trial previously lost. It is what it is intended to be - a complaints' hearing place, limited to their subject-matter and oriented to eliminate problems, rather than re-litigate. The parties, in their place, need to be disciplined to treat first instance with all due seriousness as the success or failure in it determines the overall result. ${ }^{39}$ Finality stands exactly on the same positions, yet uses other arguments to prove the cause (social $v$. economic concerns).

Last but not least there is a consideration paying attention to the purpose of the trial. With the spread of the ideas of Franz Klein (father of the social school of civil procedure and an architect of Austrian procedural reform of 1890), more and more states believe that any dispute is a problem, and the society is interested in its quick and peaceful solution. ${ }^{40}$ What we want is to restore normal relations and reconcile the parties, while the easy access to review mechanisms provokes a 'litigious mind set' and a desire to fight till the end. Sure enough, for that purpose finality is better than the lack thereof. People shall see litigation as an end process with clear start and finish. That will, apparently, promote settlements at early stages and save resources for hard cases.

37 Maria Filatova, 'Peresmotr sudebnyh aktov v poryadke nadzora i princip pravovoj opredelennosti' ('Supervisory Review of Judicial Acts and the Principle of Legal Certainty') in Tendencies of development of civil procedural law in Russia (Yuridicheskiy Tsentr Press 2008) 313.

38 SY Yakovlev, 'Cassation in Civil Proceedings: Past and Present' (2012) 121 Problemy zakonnosti.

39 More on that: Marcel Storme, 'A Single Civil Procedure for Europe: a Cathedral Builders' Dream' (2005) 22 Ritsumeikan Law Review 87.

40 Vytautas Nekrošius, 'Celi grazhdanskogo processa: ustanovlenie pravdy ili primirenie storon?' ('The Aims of Civil Procedure: Determination of Truth, or Reconciliation of the Parties?'), (2005) 4 Russian Yearbook of Civil and Arbitration Procedure 8. 
Summarizing everything said, we tend to support the view of Neil Andrews that in devising a legal system, the state balances the need for finality and certainty with the need for justice. ${ }^{41}$ While both individuals and general public are interested in certainty and stability, they also benefit from the correct application of law to the facts of the case and the fairness and legality (as fundamental aspects of justice) duly preserved.

\section{THE EXPERIENCE OF UKRAINE}

A major judicial reform has recently taken place in Ukraine. It introduced changes to all legal instruments on courts and their competence, as well as to procedural codes. As was said, the catalyst for reform was the need to modernize national law, bring it closer to the standards of EU and the Council of Europe, strengthen independence, impartiality and efficiency of the judiciary, but above all - to make it better for Ukrainian people. ${ }^{42}$

This is not just another ordinary reform, as the changes are brought to a significant number of legal provisions, starting with the highest level - that of the Constitution. On 2 June 2016 the amendments to the Basic Law were enacted, and for the first time ever introduced the term 'finality' to Ukrainian law. Under the new provision, the Constitutional Court has the power to rule on constitutionality of laws on a basis of constitutional complaint filed by a person, who considers that the law applied to his case is in violation of the Constitution. Thus, such a complaint is only available where other remedies have been exhausted.

At the same time, the qualities of a 'final judicial decision' are not formally enshrined in the Civil Procedural Code or elsewhere ${ }^{43}$ Consequently, much vagueness still remains in determining when exactly it is possible to reach the Constitutional Court. Still, if we rely on Art. 77 of the Law on the Constitutional Court ${ }^{44}$ it may be presumed that a final decision is the one approved on the appeal, and where it is subject to cassation review - decision taken in that instance. For reasons of clarity it makes sense to enshrine the term 'final decision' and its contents directly in procedural law, with a view to bringing the latter in accordance with the Constitution and the European Convention. Curious, however, is that now the CPC enshrines the notion of the 'rule of law' (as one of the principles on which it is based), without any explanation of its possible contents.

Instead of 'finality' and 'res judicata', the new law continues to rely on the well-known notion of 'legal effect'. In civil procedure this emerges in accordance with Art. 273 $\mathrm{CPC}$, which provides that (as a general rule) a court decision becomes valid (acquires legal effect) after the expiry of the time-limit for filing an appeal by all parties to the case, unless an appeal has actually been filed. In the latter case, the decision (if not dismissed) is valid after the return of appeal, refusal to open or close the proceedings or

$41 \quad$ Neil Andrews, 'The Three Paths of Justice: Court Proceedings, Arbitration, and Mediation in England' (Springer: Dordrecht 2012), 113-114.

42 Iryna Izarova, 'Reform of the Civil Process in Ukraine: Novelties of Lawsuit' (2017) 8 Law of Ukraine 33.

43 Viacheslav Komarov, Civil procedural law in the dynamics of development and practice of the Supreme Court of Ukraine (Pravo 2012), 70-73.

44 Zakon Ukrainy 'Pro Konsitucijnij Sud Ukrainy' of 13.07.2017 (The Law of Ukraine 'On the Constitutional Court of Ukraine') <http://zakon0.rada.gov.ua/laws/show/2136-19> accessed 8 December 2019. 
the adoption by the appellate instance of the ruling on the effects of appeal review. At the same time, it is still possible to apply to cassation instance and to review decisions due to newly or exceptional circumstances. However, the last two options are considered as being extraordinary forms of review, available on a limited number of grounds and subject to stricter conditions of accessibility.

The judicial reform has not spared the structure and competence of the courts. There is currently a brand-new law on Judicature ${ }^{45}$ that establishes the following system: local (district) courts, courts of appeal (functioning within special circuits) and the Supreme Court which functions as the sole cassation instance for the decisions taken in the first and appellate instances. ${ }^{46}$ However, Supreme Court also serves as an appellate instance to the decisions taken by the courts of appeal (in first instance). A positive feature of the new law is establishing that the task of the Supreme Court is to 'ensure consistency and uniformity of judicial practice. ${ }^{47}$ That means a proper distribution of responsibilities between the instances was a matter of high priority to the reformers.

From now on, the law clearly differentiates between appeal and cassation review. While the former is prima facie open to everyone and constitutes a legal principle (Art. 2 CPC), the latter is only available 'in cases provided for by the law', which makes it a more limited and less-achievable remedy. ${ }^{48}$ These statements are contained not only in CPC, but also appear (in a similar formulation) in Art. 129 of the Constitution and Art. 17 of the Law on Judicature.

The procedure for appeal is now regulated by the first chapter of Section V CPC (Review of judicial decisions). Despite that the general desire was to limit the time allowed for appeals in order for the decisions to enter into force quicker, the new law extends time-limit for lodging an appeal from 10 to 30 days (Art. $353 \mathrm{CPC}$ ). This term may be restored by the Court is the applicant files a special petition and assures the court there were substantial reasons for missing the deadline. The power of the court to restore the term is not as such contradictory to legal certainty (as it aims at protecting a valid legal interest), yet needs to be approached with all due caution. It is especially true for Ukraine where an extreme extension of terms for appeal was once found in violation of Art. 6 ECHR.

As was mentioned, the ECtHR tries to prevent any threat to finality, wherever it comes from. In Ponomaryov, such a threat has arisen from a situation where a case was overturned in the appellate instance after the terms for filing an appeal expired. ${ }^{49}$ Despite the review was not extraordinary in nature and no new proceedings were started, stability and legal certainty were actually put at risk, since the terms were restored on highly questionable grounds.

In that case, time-limit for the appeal was renewed on the grounds of (allegedly) difficult economic situation of the party that prevented it from paying the court fees. The Court

45 The Law of Ukraine 'On the Composition and Status of the Courts' of 2 June 2016 <http://kodeksy.com. ua/ka/o_sudoustrojstve_i_statuse_sudej.htm> accessed 8 December 2019.

46 See: Art. 36 of the Law 'On the Composition and Status of the Courts'.

47 The Law of Ukraine (n 45) Art. 36(1).

48 Previously, the rights to appeal and to cassation were contained in Art. 13 CPC, and the Code made no clear distinction as to the degree of their availability. Now, the new Art. 17 largely resolves that issue.

49 Ponomaryov ( n 25) 41. 
pointed out that the party alleged not the lack of funds, but rather lack of free funds to pay the duty. Moreover, there was no indication that the party had ever requested to postpone the payment or to allow it to be made in installments in accordance with relevant national law. In this situation, the party had an opportunity to bring another appeal in case a significant time-limit had been missed and the enforcement of judgment was commenced. In the Court's opinion, the application of the party was made with an intention to get a rehearing of the case rather than to correct serious judicial errors. For that reason, a violation of Art. 6(1) ECHR was found. As is clearly seen, despite the question of the renewal of the time-limit for the appeal was within the competence of national courts, their power in that regard could not be unlimited. The valid grounds for renewal could include, for example, the failure by the State authorities to inform parties of decisions taken with respect to their cases. But even in such situations the possibility of renewal had to be limited. Such a conclusion may be clearly drawn from the Court's reasoning in 'Oleksandr Shevchenko v. Ukraine' ${ }^{50}$ and 'Trukh v. Ukraine. ${ }^{51}$ In each case, the national courts were required to verify whether the grounds for renewal of the time-limits justified interference with the principle of res judicata, in particular in those situations where the national law did not restrict the powers of the courts (to take on cases and to renew the missed deadlines).

Currently, the Ukrainian law provides such a restriction in Art. 358 CPC. According to it, regardless of the reasons for missing the deadline, the appellate court shall refuse to commence proceedings if the appeal is filed after the expiry of one year from the day the full text of the court decision was completed..$^{52}$ This rule makes substantial contribution to finality as it removes the threat described above.

However, the same Art. 358 provides for exceptions in case an appeal is filed by a person who has not been notified of the trial or has not been involved in it had the court ruled on his rights or obligations. Another exclusion is allowed for situations of force majeure, the contents of which are not clearly disclosed in the Article or elsewhere in the Code..$^{53}$ For that reason, the procedure for lodging an appeal requires further clarification.

Art. 355 CPC provides that the appeal is lodged directly to the court of appeal. Further norms of the Code establish the rules the judge of the appeal (in some instances, a reporting judge) follows in deciding on the opening of the proceedings or leaving the claim without motion, its return or refusal to start proceedings. It seems that all mentioned procedural decisions shall be taken by the court of appeal or by a reporting judge by considering the materials of a civil case. Based on the above, we believe it expedient to propose such procedure for filing an appeal, where the complaint is submitted to the court of first instance. The latter, in its turn, after the expiration of the time-limits for the appeal, will transfer the complaint together with the case materials to the court of appeal. Such is the rule in the Lithuanian CPC. 
As for the scope of appeal, it is designed to be limited, rather than full-scale. The Court cannot go beyond the claims and reasons stated in the appeal, and only in exceptional cases may admit new evidence (Art. 367). Such exceptions are situations, where it was impossible to present these materials to the court of first instance for reasons beyond the control of the party. The court will not be bound by the reasoning of the parties if it establishes a manifest violation of procedural law (that shall make the decision of first instance void), and if it finds that the decision taken in special (uncontested) proceedings was clearly unfound. These last cases are obviously intended to defend public interest in civil procedure, but in their application the courts in Ukraine need to find an appropriate balance. Appeal can never be regarded as 'another first instance' and the judges shall think of their job in term of judicial control, limited to the core questions and unrelated to things that can possibly be avoided with no harm to justice and the rule of law.

In a way, the procedure of acquiring finality by a decision is influenced by a possibility of reviewing an appeal without the notice of participants to the case. According to Art. 369(1) and (2) of the Civil Procedural Code of Ukraine, appeals in claims up to one hundred living wage for persons of working age (except those that cannot be heard in simplified proceedings) shall be dealt with by the court of appellate instance without the affected parties being notified. The same rule is established for appeals against court orders referred to in Art. 353 CPC, paras. 1, 5, 6, 9, 10, 14, 19, and 37-40.

In this regard, it is worth noting that the implementation of such provision, to the author's opinion, will not contribute to ensuring the accessibility of justice. On the contrary, it presents a form of interference with the access of citizens to the court. Natalia Sakara reasonably advocates the establishment of the methods and mechanisms of overcoming such problems, as well as the conditions or factors that can guarantee the most favourable circumstances for the implementation of the right to judicial protection, ${ }^{54}$ inter alia, in the court of appellate instance. This is quite different from participation of the parties in the court of cassation, in which several limitations may be validly justified. The latter form of review is of extraordinary nature, and due to that reason is not as easily accessible to general public. This follows from the requirements of the Convention and the practice of the ECtHR. Thus, in Monelean v. Sweden (Judgment of February 22, 1984) and Maurice v. Sweden (Judgment of March 2, 1987), the question arouse of the possibility to derogate from the principle of oral trial, which presumes that a person needs to be present during the hearing and be able to defend his/her position, taking into account the peculiarities of national procedural law. The Court ruled that if the trial in the court of first instance was open, the absence of a person's participation in the courts of higher instances could be justified by the peculiarities of the procedure. If the complaint concerns only the matters of law, but not fact, then, in the Court's opinion, the requirements of the open trial are fulfilled even when the applicant was not given the opportunity to be heard personally in the court of cassation. ${ }^{55}$

Ukrainian appellate instance is, however, an ordinary form of review and the one which presupposes determination of both law and facts. For that reason, it seems superfluous

54 Natalia Sakara, The problem of access to justice in civil cases (Pravo 2010).

55 Volodymyr Averyanov et al (eds), The Constitution of Ukraine: scientific and practical commentary (Pravo 2003) 648-649. 
to limit the rights of the parties to participate in trial or, at least, to be made aware of the date and place of hearing.

The institute of cassation has also been changed a lot. As was mentioned, it is available only in cases, provided by the law. Thus, for the first time in Ukraine certain filters are introduced in cassation instance. The CPC establishes that reasons for cassation review include incorrect application of substantive law or violation of procedural law. Only those decisions that passed through appeal can make their way to cassation (which is now placed at the newly established Supreme Court).

It is also important that a decision may be reviewed in this procedure only once. Previously it was a problem for Ukrainian legislation, and in Sovtransavto it was held that repeatedly setting aside of judgments [in post-final procedures] is incompatible with legal certainty. ${ }^{56}$ Finally, cassation becomes an institute of extraordinary, and not of regular, nature.

Access to cassation is closed for certain categories of cases, which include: (1) decisions that are subject to appellate review in the Supreme Court; (2) decisions in small (of little importance) cases. The latter category, however, presupposes its own exceptions (when the review may actually take place). Among them: fundamental relevance of the case for precedent-formation; lack of possibility for the person to dispute the circumstances established by the court in another case; significant public interest or exceptional importance to the participant in the case who submits the cassation complaint; prior characterization of a case as 'of little importance' made by mistake.

The ECtHR has agreed that the limitations on cassation are a matter within internal regulation of each state, and national authorities possess a wide margin of appreciation here. They are allowed to apply various filters, limit access for certain categories of cases and introduce other restrictions as long as they are in accordance with the right of access to justice and are not arbitrary and discriminating. In Trukh, for example, there was no violation when the national court required the payment of a State tax. ${ }^{57}$

The new provisions of the Code may be misleading in practice. There is no established definition of Icases 'of little importance' and no clarity with the criteria for the mentioned exceptions. In fact, the very limitation for cases of little importance seems unnecessary, as in almost any situation it can be overcome by one of the corresponding exceptions. For that reason, it would be better to give more discretion to the Panel of the Supreme Court in deciding, which cases may be admitted for a cassation review. Of course, for that purpose it will need a set of guidelines that shall have nothing to do with the monetary value of the case, but rather refer to its importance for the development of uniform practice and development of law.

Some other restrictions are provided in Art. 394 CPC. Thus, the Supreme court may declare the complaint unreasonable and refuse to open proceedings if it has already given its decision on the application of the rule relied on in the

56 Sovtransavto Holding v Ukraine, ECtHR Judgment (2002), Application No 48553/99, 77.

57 Trukh (n 51). 
complaint, or if the correct application of the rule seems obvious and does not cause reasonable doubts as to its application or interpretation. Such power may be exercised only in relation to cases that are under 500 living wages for persons of working age. This distinction may seem artificial, as the same problem (statement of a problem that has already been solved) may occur with relation to any case, whatever its monetary value is. Consequently, the Supreme Court will not have the chance to get rid of them in the same fashion, while its work will be certainly limited to repeating its old reasoning.

Finally, the Court is obliged to refuse to open proceedings in cases for review of the ruling on the return of the application to the plaintiff (the applicant), the consideration of complaints on actions (inaction) of the bodies of the state executive service, the private executor where the decision of the cassation court on the consequences of considering such a complaint will not contribute to formation of a single law enforcement practice. This limitation is probably justified by the tasks and mission of the last instance, but its application in practice is yet to be seen. Surprising only is that such power of the Court only exists for some administrative (public) cases, while most other complaints can easily reach cassation regardless of their relevance for the uniform law enforcement practice.

Finality of judgment of the appellate and cassation courts is also negatively influenced by the possibility of reviewing the cassation complaint filed after the hearing of the complaint had taken place (Art. 405 CPC of Ukraine). As a result of such procedure a court of cassation may overturn its own decision, which leads to the loss of its finality. The mentioned rule provides that where a cassation complaint reaches the court of cassation after examination of the case is over, and the complainant has not been participating in the trial, the court hears such complaint under the rules of cassation proceedings. In case the proceedings are opened on the basis of such complaint, the court of cassation may suspend the effects of previously adopted resolutions and appealed decisions. The court of cassation examines the complaint within the limits of the arguments that were not previously discussed under the complaint of another participating party.

Following such examination, the court gives its ruling. In case the relevant grounds are present, the previous decision of the cassation court may be dismissed. This form of self-control, despite known to some other national jurisdictions, and reasonable for the sake of access to justice and equality before law and court, can have a negative impact on the finality of judgment and lead to continuing uncertainty as to the legal status of case participants.

Last but not least, court decisions may be reviewed under newly discovered or exceptional circumstances, under the rules of Chapter 3 Section V CPC. Luckily, in this case the Code further clarifies what both of these are. The procedure itself contributes to legality and correct application of the law. Most of the grounds for this type of review are typical for such form of proceedings and do not require further comments. For Ukraine, however, it is extremely important that the new Art. 424 CPC not only establishes certain time-limits, but also stipulates their preclusive nature: their restoration is not allowed on any grounds. 


\section{THE EXPERIENCE OF LITHUANIA}

The ideas of finality and stability of judicial decisions play a significant role in both constitutional and procedural legislation of Lithuania, since there is always a natural need to ensure human rights and endurance of legal relations, as well as to maintain the authority of the judiciary and public confidence in it. ${ }^{58}$

The same old 'legal force' term is still used to describe qualities a judicial act acquires on becoming final and binding. It becomes indisputable, prejudicial (predetermined for all future disputes on the points provided therein) and may be executed (Art. $281 \mathrm{CPC}$ of Lithuania). The notion of res judicata belongs rather to academic literature, where it is revealed as an official prohibition of lodging identical claims and a powerful tool to prevent raising of contradictory facts..$^{59}$ Judicial proceedings cannot last indefinitely, and the sole persistence of dispute between parties should not inevitably oblige the court to consider their arguments on the merits time and again - these are the ideas that have become - not without help of the $\mathrm{ECtHR}^{60}$ - a part of contemporary Lithuanian law and order.

In the same way, the legal system relies heavily on the ideas of concentration and judicial economy (Art. 7 CPC of Lithuania), hearing of the case within a reasonable time, etc. These rules and policies also place a limitation on the total length of proceedings (including the time necessary for review) and, in principle, demand concentration of all relevant proceedings in the court of first instance ${ }^{61}$ Important to note also is that the CPC is intensively pushing the idea of 'conflict elimination' as one of the purposes of civil litigation. This goes in line with some of the ideas of Franz Klein on the Sozialfunktion of civil procedure expressed back in 1890-s during the reform of Austrian civil procedural law. In terms of finality it means that 'the lesser litigation - the better litigation [is]'. Consequently, repeated trials, extensive appeal possibilities and reopening possibilities go against these goals and are definitely not welcome in modern-day Lithuania.

This does not necessarily imply a total impossibility of changing or cancelling a decision (with a reversal of res judicata). The legal force does not imply absolute immunity from checking for the presence of legal or factual errors. ${ }^{62}$ However, Lithuania tries to minimize such possibilities and leave only the required remedial minimum.

There are three possible ways to overcome legal force of a judicial act: (1) appellate process (apeliacija), (2) cassation (kasacija) and (3) renewal of trial (proceso atnaujinimas). All three are comprehensively regulated by Part III CPC of Lithuania. The formerly known supervisory procedure (priežiūros procesas) has been abolished as contradicting to the modern Lithuanian legislation and its fundamental principles (i.e. judicial independence). The reduction of instances and limitation of opportunities for

58 Egidijus Laužikas, Valentinas Mikelènas, Vytautas Nekrošius, Civilinio proceso teisè (2 tomas) (Justitia, 2005) 167.

59 Egidijus Krivka, 'Res judicata principo igyvendinimo grupès ieškinių procese problemos' (2004) 53(45) Jurisprudencija 54.

60 Indrè Jocytè, Indrè Venslovaitè, 'Res judicata principas teismų praktikoje’ (2017) 1(15) Teisès apžvalga 113.

61 Virgilijus Valančius, 'Lietuvos civilinio proceso kodeksas: pirmųų metų patirtis' (2005) 69(61) Jurisprudencija 54.

Knyazkin (n 18) 63. 
bringing appeals can be definitely seen as a victory of stability and inviolability of the judgments initially given.

In practice, the judicial system functions as follows. Civil cases are dealt with in first instance by local (apylinkes teismai) and district (apygardos teismai) courts. The former are busy with majority of private disputes, while the latter are only available in more complex proceedings (Art. 27 CPC of Lithuania). District courts also hear appeals to the decisions of the local courts, while their own judgments in the first instance may be appealed to the only institution - the Lithuanian Court of Appeal (Lietuvos apeliacinis teismas). Cassation as a separate instance is designed to hear complaints against those decisions that have already entered into force. The only competent authority in such matters is the Supreme Court (Aukščiausiasis Teismas), a place of ultimate redress for all civil claims within the state. ${ }^{63}$ Its decisions may no longer be reviewed by any other body (including the Court itself). Renewal of the trial deserves special attention since this stage remains independent and extrainstantiational, available with respect to decisions of any instance under the conditions provided by the law.

The first and most accessible form of control is the appeal. It cannot be regarded as an exemption from the general rule of res judicata, as the decision has not entered into force by the time the petition for appeal is lodged. Therefore, it has not yet become 'settled' and 'closed for consideration'. Parties may still have two separate views of the subject-matter and wish to defend their case. Moreover, Lithuania follows the example of some Western states, where the right to appeal is enshrined in constitutional law and considered an integral part of the right to judicial protection (in terms of access to courts). In this way, such form of review does not contradict the principle of legal certainty, and, on the contrary, duly secures the right to fair trial (Art. 6 ECHR), since a person needs to have not only the right to lodge a claim in first instance, but also a remedy against an unlawful and biased verdict produced there. This is especially true where a single judge is responsible for taking decisions and the risk of error is reasonably high.

In Lithuania, the Constitution does not explicitly mention such a possibility, however the norm eventually acquired recognition in the jurisprudence of the Constitutional and Supreme Courts. Both of them gave a broad view of Art. 30 Constitution (on the right to judicial protection) and found that the right to appeal is an integral part of it.

At the same time, this does not mean that no restrictions are placed on the proceedings in second instance. The one that immediately comes to mind is time-limit: a party has 30 days of the date a judicial decision is issued to lodge an appeal (Art. 307 CPC of Lithuania). This term is not preclusive and may be restored, the applicant having submitted a petition in that regard. If that happens, the court will, in a legal sense, put a dispute already resolved back into a state of uncertainty (until the decision in the appeal is taken). That is why the legislator is approaching such delicate situation with all due thoroughness and does not provide for an unjustified extension of the right to restore. Firstly, there is a time-limit of 3 months to lodge a petition, running since the

63 Teismu isstatymas, Nr I-480 (31 May 1994), Art. 23 <https://e-seimas.lrs.lt/portal/legalAct/lt/TAD/ TAIS.5825?ffwid=fhhu5mvyf $>$ accessed 8 December 2019. 
announcement of the decision in first instance. After its expiration, the right to appeal is exhausted and a person is further precluded to call the merits of the case into question. ${ }^{64}$ Secondly, even within a three-month period, the court evaluates the reasonableness of applicant's conduct and the importance of arguments presented for appeal.

Timely submission of an appeal postpones the moment the decision enters into force. The dispute is not yet considered to be resolved: it continues in the second instance, thus most provisions regulating proceedings in lower courts are equally applied there. Despite that, Lithuania opted for a limited rather than a full model of appeal. While the latter presupposes re-examination of the case, the former just involves a form of control over legality and validity of the decision pronounced in first instance. ${ }^{65}$ That is why it limits the possibility to raise new claims, bring new evidence and hold repeated hearings (since the written form of proceedings predominates). The limited model is more consistent with the ideas of stability and finality of judicial decisions. Little by little this model is being adopted in most European states, not least due to the role of the Recommendation of the Council of Ministers already mentioned before.

It must be admitted though that the limits for appeal are justified not only by the ideals of finality, but also by the principles of concentration and judicial economy. The two require key litigation issues to be determined in first instance due to its proximity to the case and the parties. A complete repetition of all procedural steps taken in first instance would increase the time for consideration of the case and the costs of proceedings, as well as create an additional burden on the judiciary. The so-called 'litigious mind set' should not be promoted among the population. In no way shall the parties believe that the first instance is just a 'test of strength', whereas a genuine judicial combat occurs at a later stage. In this regard, the current legislation carefully promotes their proper preparation for the trial already in the first instance and encourages presenting all relevant arguments and evidence before it. ${ }^{66}$

Neither the raising of new demands, nor the submission of new evidence is allowed ${ }^{67}$ in the appellate instance (Art. 314 CPC of Lithuania). The last prohibition, though, is not absolute: the court may accept additional evidence in case the court of first instance refused without grounds to accept it or where the necessity of submitting such evidence arose later. The evidence that proves non-substantiation of the actions and decisions taken in the first instance, as well as the modified claims for the award of penalties and interest shall not be considered new either.

Appellate proceedings presume checking a case on both factual and legal grounds. Still, it will be handled only within the boundaries that the appellant herself sets up in the complaint (it is always possible to dispute only a part of judgment). The court

64 Goda Ambrasaite, 'Apeliacinis procesas: pagrindinès civilinio pproceso kodekso naujovès' (2003) 37(29) Jurisprudencija 8.

65 Ambrasaite (n 64) 9. These two opposite models of the appellate instance are sometimes referred to as trial de novo and trial revisio prioris instantiae.

66 Michail Bron, Salomėja Zaksaite, 'Teisè apskųsti pirmosios instancijos teismo sprendimą kaip pamatinè konstitucinè teisë' (2008) 66(2) Teisè 146.

67 Lietuvos Aukščiausiojo Teismo Civiliniu bylų skyriaus teisèju kolegijos $2007 \mathrm{~m}$. vasario $19 \mathrm{~d}$. nutartis civilineje byloje Nr. 3K-3-52/2007 <http://www.teisesgidas.lt/lat.php?id=30951> accessed 8 December 2019. 
may however dispense with these limitations if so required by public interest. In addition, the court checks ex officio the violation of those procedural rules that present unconditional grounds for cancelling decision (Art. 329 CPC of Lithuania). These include: an illegal composition of the court, a court's ruling on the rights or obligation of persons not involved in the trial, a decision taken not by the trial judge, an absence of court's reasoning in the decision, an absence of the minutes where the case was heard in oral proceedings, violation of patrimonial jurisdiction and failure of the first instance court to rule on all matters of the lawsuit. Two additional grounds are: the inadequate notification of persons involved in the case and the resolution of dispute in violation of the rules on language of the proceedings (however, these two are only checked at the request of the appellant).

In case a miscarriage of justice is found the court of second instance can either adopt its own decision (changing or cancelling the original one), or return the case to the first instance for reconsideration. Here the legislator once again opts for judicial economy: where an error may be quickly eliminated on appeal, there is no need to send the whole case back requiring the parties and the court to repeat unnecessary procedural steps. Such a solution is well in accordance with legal certainty, the latter being damaged by any undue delays. Yet, participation in the second instance cannot always replace the proper lack of the first one, since the procedures in the two are not exactly the same. That is why, as an exception, it is still possible to dismiss the original decision and send the case back for a fresh hearing. In these situations, the court is required to indicate one of the grounds provided by the Code or to demonstrate impossibility of resolving the problem on the merits in appellate instance.

It is worth noting that a judgment, legitimate and justified per se, cannot be overturned on purely formal grounds (Art. 328 CPC of Lithuania). This again meets the desire for stability, since otherwise the judgment could easily be cancelled due to non-essential flaws. The grounds for unconditional cancellation of a decision set in the CPC are not seen as 'formal violations', since they demonstrate its unjustness and violation of the rule of law and fair trial. In presence of such grounds, the decision shall not enter into legal force and become binding.

Despite all these limitations, appellate proceedings are still an ordinary form of revision: it is applicable to all civil cases and available for all categories of applicants, since the dispute is not deemed exhausted until the decision becomes valid and acquires the force of res judicata. The legislative provision that existed before, limiting possibility of appeal to claims over 250 LT (approx. 72 EUR), was lifted after 2011 due to the position expressed by the Constitutional Court on the essence of the appeal.

The second form of control known to Lithuanian law is cassation. It is available with respect to decisions that have already become final and binding. Thereby it is a more radical measure having a direct impact on the stability of judgments. Several legislative tools are aimed at minimizing the negative effect of this type of review in relation to judgments that are being (or have already been) implemented. First of all, cassation is in no way as accessible as the appellate proceedings are. It may take place only on the grounds enumerated by the Code (Art. 346). These include: (1) violation of substantive or procedural rule(s), in case it has an essential significance for the uniform 
interpretation and application of the law (if that violation could have affected the adoption of a wrongful judgment); (2) deviation of the previous court from the relevant case law of the Supreme Court on the same subject; (3) lack of uniform case law of the Supreme Court on an issue raised in the complaint (and the need to establish it).

Cassation is possible where any of these grounds is present. At the same time, the applicant shall not only indicate its presence, but also provide a proper legal justification of his complaint. Nevertheless, even this does not guarantee that the case will be accepted for examination, due to a permissive system existing in the Supreme Court. All incoming cassation appeals are sent to a special panel that possesses a wide discretion in selecting cases for further hearing on the merits. More than a half of incoming disputes are being rejected by the panel, while its own decisions are not subject to any appeal.

These strict limitations are justified by the special tasks put before the Supreme Court. The mentioned CoE Recommendation emphasizes that a redress to such a body shall be exclusive and available only in cases which merit a third judicial review, e.g. which would develop the law or contribute to its uniform interpretation. An extraordinary status of the cassation was also stressed by the Supreme Court, when it declared that an unconditional hearing of the case before it does not constitute an applicant's right (and an integral part of the right to judicial protection, as is the case with the appeal), but rather represents an exclusive form of control over legality of judicial decisions. ${ }^{68}$

The mechanism of cassation serves not only private, but also public interests. There is no doubt that it is aimed at correcting judicial errors that initially have led to an unjust decision. However, at the same time it is called upon to provide trust to the judicial system, to explain legal provisions, to establish new precedents and to promote the progressive development of law. That is why cassation powers are entrusted to the sole and the highest body in the judicial hierarchy - the Supreme Court of Lithuania. Legislative restrictions and the permissive system allow for only those cases that actually help developing law and ensuring its uniform application make their way to the cassation review.

Despite the preponderance of public interests, the right to bring a case to the Supreme Court belongs to persons participating in the case. They have 3 months from the date of entry into force of the disputed decision, and they lose the right to renewal after 6 months since the same date.

The second significant limitation of cassation proceedings is the prohibition to commence them bypassing the appellate instance. The case may be heard by the Supreme Court only after it has been consequentially heard in two lower instances (Art. $341 \mathrm{CPC}$ of Lithuania). At the same time the monetary-related limitation has now been lifted (previously in disputes over property with a ceiling of 5,000 LT (1,500 EUR) no cassation was allowed), as it constituted discrimination and was seen as an obstacle to the access to justice for certain categories of citizens. It is now believed that even disputes on a small amount may raise an issue important for the case law, and therefore

68 Lietuvos Aukščiausiojo Teismo Civilinių bylų skyriaus Atrankos kolegijos 2009 m. lapkričio 30 d. nutartis, Nr. 3P- 1435/2009 <https://eur-lex.europa.eu/legal-content/LT/TXT/?uri=CELEX\%3A62016TJ0561> accessed 9 December 2019. 
the right to 'pick' cases for cassation review shall lie with the panel of the Supreme Court, rather than be based on a peremptory norm of the Code.

As for the procedure in cassation, it is important to note that only questions of law (but not of fact) are examined there. The Court controls respect for the laws by the lower instances and the unity of their interpretation, but takes the facts and legal relations previously determined as is. ${ }^{69}$ This allows to reduce court expenses and duration of trial, get rid of analyzing legal relations of the parties by concentrating on solving purely doctrinal questions of law enforcement. The possibility to go beyond the boundaries of a submitted complaint exists in exceptional cases, where the public need requires that. Case hearing in cassation does not suspend the enforcement of the contested judgment, due to the presumption of its validity and compulsory nature. The case may be heard in cassation only once (Art. 340(3) CPC of Lithuania), i.e. second cassation or supervision are impossible, and the final decision of the Supreme Court is 'final' in true sense of the word.

The Court has the power to change a previous decision, dismiss it wholly or in part, as well as to maintain one of the acts taken in previous instances (in case it correctly applied the law to the facts).

In sum, we may conclude that the activity of the Supreme Court always implies a careful balancing of fairness of judicial decisions and stability of legal relations. In legal doctrine, the term 'third instance' is never used to describe the essence of cassation, since the latter is not easily accessible and has nothing to do with revision of the factual side of the case. Its limitations only highlight the importance of the first instance, which cannot be substituted even by the highest judicial authority in the country.

The ultimate opportunity to influence the fate of decision is the reopening of proceedings. Just like the cassation, this stage constitutes an extraordinary remedy, available only on the grounds established by law. The difference is that reopening also constitutes an extrainstantional method of control and not a kind of appeal: there is no complaint as such in respect to any previous court decision, but rather a request to resume litigation of a particular dispute. What is of interest to us is not the terminology used, but the result to be achieved by invoking this measure. One does not need to go far to learn that the latter may be the loss of res judicata by a judicial decision.

The purpose of the reopening is to ensure the rule of law within Civil Procedure. The court looks for the existence of one of the specific circumstances and decides whether the case actually deserves re-examination on that basis. The circumstances are the following: (1) adoption by the ECtHR of the decision on violation of the Convention by Lithuania while handling a particular case; (2) disclosure of a newly discovered essential fact (which was not and could not be known to the applicant); (3) establishment in the court verdict of unlawful actions by a party, a third person, a witness or an expert in the proceedings of the case; (4) establishment in the verdict of unlawful actions of a judge in the proceedings of the case; (5) dismissal of a court decision or an act of law enforcement that was a basis to the decision in question; (6) incapacity of the party to

69 Valentinas Mikelenas, 'The development of civil procedural law in Lithuania in the period 1990-2015' in Dmitry Maleshin (ed), Eurasian civil process: to the 25th anniversary of the CIS and Baltic countries (a collection of scientific articles) (Statut 2015) 176-202. 
the dispute if there was no representative in the case; (7) adoption by the court of a decision on the rights and obligations of persons not involved in the trial; (8) resolution of a dispute by an illegal composition of the court; (9) an obvious legal error that was committed by the court of first instance (provided the case was not duly appealed).

Reopening of procedure provides an opportunity to correct significant judicial errors and, accordingly, protect both private and public interests. The availability of this option is a necessary minimum to guarantee the rule of law. In case one of the named circumstances is known to the party, but the deadline for resorting to the appellate or cassation instances is missed, this measure remains the sole possibility to seek justice. Moreover, ground (7) is especially designed for persons who did not take part in the case. For them an ordinary type of review is unavailable, thus they have no other way to defend their rights.

At the same time, even such form of revision shall have certain limitations. The first of them is temporal: a request to the court must be made within 3 months since the time the person learned or should have learned of the relevant circumstances. The ultimate deadline to ask for resumption of procedure is 5 years from the moment an original decision was taken. Another limitation is the prohibition to reopen proceedings in matrimonial matters if they concern dissolution or annulment of marriage and at least one of the parties has concluded a new marriage. Such a restriction is justified not only by legal certainty, but also by ethical aspects of family relations (as well as potential interests of children from a new marriage).

The competence to decide on reopening of proceedings belongs (in most cases) to the court of first instance. Having established the actual existence of relevant circumstances and assessed their impact upon the substance of the dispute, the court has a power to change or even dismiss its own previous decision.

There is a possibility to apply to the court with a request to reopen proceedings on the same ground only once. If the court does not grant this request or refuses to admit the case, a person is precluded to take further actions on the same set of facts (Art. 374 CPC of Lithuania).

\section{POSSIBLE IMPLICATIONS FOR THE TWO NATIONS}

We can clearly see that both in Ukraine and Lithuania the problem of finality of judicial decision is approached through the prism of legal effect of judicial decision. However, legal effect has certain limitations, which makes it possible to appeal the judgment and deprive it of res judicata effects.

It may seem that most problems of the two countries lie with review system, and are associated with the struggle to drive it away from Soviet nadzor to a well-balanced Western approach of limited and 'targeted' intervention in the judgment's finality. Still, problems are found elsewhere, too. Thus, in Esertas the ECtHR found a violation of issue preclusion (one of the main features of res judicata), which was protected not only by the Convention, but the national law as well. ${ }^{70}$

Both Lithuania, and Ukraine try to settle a clear and comprehensive system for the

Esertas (n 15) 31 . 
review of judgments, limit the number of instances and distinguish between the tasks of their judges. Still, sometimes it happens that one and same judicial body has several functions - such is the case with the Supreme Court of Ukraine which serves as both cassation and appellate institution (the latter function is performed in relation to decisions of the courts of appeal taken in first instance). In contrast, Lithuania solved a similar problem (though, not in the most elegant way) by establishing a separate Court of Appeal only to deal with appeals to the decisions of regional courts. It helped to relieve the Supreme Court from the caseload and undue extension of competence.

In Ukraine, unlike Lithuania, cassation is still more 'ordinary' a stage than the instance with the same name in Lithuania. While the latter state clearly restricts public access to that remedy and speaks frankly of its public purposes, Ukraine tries to maintain the balance and allow more cases to reach that phase. Well, next there go exceptions, and then - exceptions from them - and it all makes the rules quite complicated and the actual position of the applicant, defendant and judge quite vague. Such uncertainty leads to divergent interpretations and, quite likely, some of them would not be in accordance with ECtHR standards of finality.

It is also to note that Ukraine seemingly does not draw so much attention to the other relevant considerations, such as judicial economy, concentration and the goals of civil litigation (resolution vs. settlement of the dispute), at least in their application to the problem of finality. Some of the provisions seem old-fashioned, and some require further clarifications and comments.

Lithuanian law, in fact, is also far from perfect. The country has succeeded in implementing provisions of the CoE Recommendation and modifying its appeal and cassation institutions, though there are still debates on the potential scope of these review instances and the powers given to the courts in that regard.

\section{CONCLUSIONS}

The main dilemma was always between the right of access to court and the principle of finality. On the one hand we have the necessity to guarantee a private party judicial protection and remedies for all possible situations (i.e. against another party, against a biased court, against a court of second instance, etc.). On the other side lie the thoughts of stability of relations, conflict prevention, judicial economy. At the same time, both considerations can be seen as emanations of the core principle of the rule of law. Each state is given power to design its legislation in such a way as to take account of both considerations. Fortunately, we have European Court of Human Rights and other supranational institutions to provide meaningful guidance. Neither Ukraine, nor Lithuania shall neglect the solutions reached by the Court on Art. 6 ECHR that involve res judicata / legal certainty (even when these are given in relation to third states). The great advantage of ECtHR lies in the fact that it looks at the essence of the problem with finality and not solely at formal legislative statements. For that reason, it was able to find violations where no one ever knew they had existed. In order to build a more perfect judicial system it is also relevant to take a complex view, and when the reforms are being introduced - not to limit their reach for one or several parts of the Code, but rather take due attention of the whole system. 